\title{
Study of the Presence of Radon in Groundwater from Two Regions in Saudi Arabia
}

\author{
Ahmed El-Sharkawy' ${ }^{1}$, Hanan Al-Ghamdi ${ }^{*}$ \\ ${ }^{1}$ Nuclear and Radiological Regulatory Authority, Cairo, Egypt \\ ${ }^{2}$ Physics Department, College of Science, Princess Nourah bint Abdulrahman University, Riyadh, KSA \\ Email: ahmedtharwat741@gmail.com, *hmalghmdi@pnu.edu.sa
}

How to cite this paper: El-Sharkawy, A. and Al-Ghamdi, H. (2018) Study of the Presence of Radon in Groundwater from Two Regions in Saudi Arabia. Journal of Water Resource and Protection, 10, 654-662. https://doi.org/10.4236/jwarp.2018.107037

Received: May 6, 2018

Accepted: July 7, 2018

Published: July 10, 2018

Copyright ( 92018 by authors and Scientific Research Publishing Inc. This work is licensed under the Creative Commons Attribution International License (CC BY 4.0).

http://creativecommons.org/licenses/by/4.0/

Open Access

\begin{abstract}
Groundwater samples with high total dissolved solids (TDS) were collected from private wells in Al Sharqiya and Tabouk regions in Saudi Arabia to determine the ${ }^{222} \mathrm{Rn}$ activities and to investigate the factors that may control the presence of radon in these wells. The radon activity levels in Al Sharqiya groundwater wells showed an average value below the maximum contaminant level proposed by EPA for drinking water. In contrast, all the sampled wells in Tabouk region exhibited ${ }^{222} \mathrm{Rn}$ concentrations exceeding $300 \mathrm{pCi} / \mathrm{L}$, the maximum contaminant level (MCL) recommended by the USEPA, which may be explained by the nature of aquifers in both regions. Within the limited number of groundwater samples, it was observed that the radon content of $\mathrm{Al}$ Sharqiya sampled wells has good correlations with some chemical parameters (TDS and Eh) in these wells. The observed correlations between the water chemistry and the radon activities in groundwater do not necessarily imply a relationship between the two events. Furthermore, these chemical parameters may reflect the presence of nearby radium in rocks surface. Radon wasn't influenced by the chemical environment in the investigated Tabouk wells but, may be is more controlled by other factors: the direct parent ${ }^{226} \mathrm{Ra}$ content and the nature of the aquifer matrix (grain size and permeability in the Saq aquifer rocks).
\end{abstract}

\section{Keywords}

Radon, Groundwater, Radium, RAD-7, Gamma Spectrometry, Saudi Arabia

\section{Introduction}

Radon as a noble gas has three natural isotopes: ${ }^{219} \mathrm{Rn},{ }^{220} \mathrm{Rn}$ and ${ }^{222} \mathrm{Rn}$. As radon $\left.{ }^{222} \mathrm{Rn}\right)$ is the direct daughter of ${ }^{226} \mathrm{Ra}$, its presence in groundwater is attributed to 
the content and decay of ${ }^{226} \mathrm{Ra}$ in the reservoir rock [1] [2]. The alpha radiation, which is emitted by radon and its decay products, can be of significant health hazard, as they may cause at certain levels lung cancer [3] [4]. In groundwaters, radon exists with concentrations that may vary between different aquifers depending on the ${ }^{226} \mathrm{Ra}$ content, lithology and geologic structure [5]. Within the frame work of the project accomplished by the physics department in Princess Nora University for the determination of the natural radioactivity levels in groundwaters of Saudi Arabia [6], this study was carried out to gain a general understanding of the distribution of radon in drilled wells at two selected regions in Saudi Arabia, and to investigate the factors that may control the presence of ${ }^{222} \mathrm{Rn}$ in these wells. The results will also be utilized in future work in the assessment of public health risks.

\section{Methodology}

This study is concerned only with ${ }^{222} \mathrm{Rn}$ because it is the direct daughter of ${ }^{226} \mathrm{Ra}$ to investigate if there is any correlation in this study, and the other radon isotopes have half-lives of few seconds. The term "radon" refers to ${ }^{222} \mathrm{Rn}$ and "radium" to ${ }^{226}$ Ra.

\subsection{Sampling}

Groundwater samples were collected from seventeen private wells in Tabouk and Al Sharqiya regions in Saudi Arabia for radiometric, physical and chemical analyses. In Tabouk, eight groundwater samples were collected from scattered wells that located between $(36.0$ - 36.9) long and (28.0 - 29.1) lat. For Al Sharqiya region, the sampled wells were located between (50.0 - 50.2) long and (26.2 26.5) lat. The water samples were allowed to run in a continuous flow for a short period, transferred into large polyethylene containers for radon measurements. A special $250 \mathrm{~mL}$ glass bottle (Durridge RAD-7) [7] was immersed in the water sample and filled with utmost care to avoid the water disturbance and eliminating air and closed carefully for radon measurements on-site. For radium, five liters were filtered with $0.45 \mu$ membrane filter, collected in polyethylene containers and acidified. For chemical analysis, the water samples were collected in suitable bottles without the acidification step and some chemical parameters; $\mathrm{pH}$, total dissolved solids (TDS), redox potential (Eh) and temperature were monitored.

\subsection{Radioactivity Measurements}

Radon measurements were carried out immediately after sampling at each site using a silicon semiconductor detector (RAD-7) supplied by Durridge Co. The RAD-7 converts alpha radiation directly to an electric signal and has the possibility of determining electronically the energy of each particle, allowing the identification of the isotopes $\left({ }^{218} \mathrm{Po},{ }^{214} \mathrm{Po}\right)$ produced by the radiation decay of the radon parent [8]. The radium activities in water $\left({ }^{226} \mathrm{Ra}\right)$ were determined by ex- 
tracting the radium from four liters sample volume using strong cation exchange resin following the procedure described by A. El-Sharkawy et al., 2013 [9] and the resin samples were measured by gamma spectrometry using high purity germanium detector of relative efficiency $40 \%$.

\subsection{Quality Assurance}

For quality assurance and validation purpose, some guidelines of the ISO 17025 technical requirements were followed through the sampling, radio analyses and validation of methods [10]. The RAD-7 detector has been calibrated annually at Durridge, USA. Replicate samples of IAEA reference water (IAEA-423 and IAEA-431) were analyzed following the same procedure, and accuracy and precision were determined for the associated replicate measurements. The accuracy was determined by the closeness of agreement between the laboratory measured values and the true values of the IAEA reference samples (\% Accuracy $=($ Measured value/True value) $\times 100$ ).

For the estimation of uncertainty, errors were propagated due to photopeak counts, standard tracer activities, sample weight and volume. The minimum detectable activity (MDA) for ${ }^{226} \mathrm{Ra}$ in water by gamma spectrometry was determined according to the equation presented by Currie [11] and was found to be $0.05 \mathrm{~Bq} / \mathrm{L}$. For validation of the gamma spectrometric procedure, water samples with different activities of ${ }^{226} \mathrm{Ra}$ were analyzed by alpha spectrometric method described by S. Nour et al., 2004 [12] as a comparison with the gamma results, and showed a good correlation as shown in Figure 1.

\section{Results \& Discussion}

\subsection{Radon in Al Sharqiya Groundwaters}

Table 1 presents the activity concentrations of radon and radium in Al Sharqiya groundwater samples and the results of some water chemical parameters.

Table $1 .{ }^{222} \mathrm{Ra}$ and ${ }^{226} \mathrm{Ra}$ in Al Sharqiya groundwater samples $\pm 1 \sigma$ uncertainties and the associated water chemistry results.

\begin{tabular}{ccccccccc}
\hline Well & $\mathrm{pH}$ & $\mathrm{T}$ & $\mathrm{Eh}$ & $\mathrm{TDS}$ & $\mathrm{Rn}-222$ & \pm & $\mathrm{Ra}-226$ & \pm \\
\hline Code & & ${ }^{\circ} \mathrm{C}$ & $\mathrm{mV}$ & $\mathrm{mg} / \mathrm{L}$ & $\mathrm{pCi} / \mathrm{L}$ & & $\mathrm{pCi} / \mathrm{L}$ & \\
W1 & 7.12 & 33.1 & 215.5 & 2170 & 307.9 & 18.1 & 6.49 & 0.3 \\
W2 & 7.44 & 33.8 & -29.9 & 3650 & 243.95 & 14 & 13.1 & 0.7 \\
W3 & 7.68 & 33.6 & -37 & 3390 & 212.6 & 12.3 & 37.1 & 1.5 \\
W4 & 7.46 & 32.1 & -30.6 & 3430 & 274.05 & 15.7 & 28.3 & 1.5 \\
W5 & 7.22 & 30.3 & -16.6 & 3520 & 214.4 & 12.5 & 3.4 & 0.2 \\
W6 & 7.66 & 32.9 & -42.2 & 4350 & 163.55 & 9.2 & 14.85 & 0.7 \\
W7 & 7.42 & 32 & -28.1 & 3430 & 268.7 & 16 & 5.42 & 0.3 \\
W8 & 7.31 & 30 & -19.7 & 3660 & 191.05 & 10.8 & 3 & 0.2 \\
W9 & 7.34 & 31.2 & 191.4 & 2440 & 315.2 & 18.4 & 4.6 & 0.3 \\
\hline
\end{tabular}




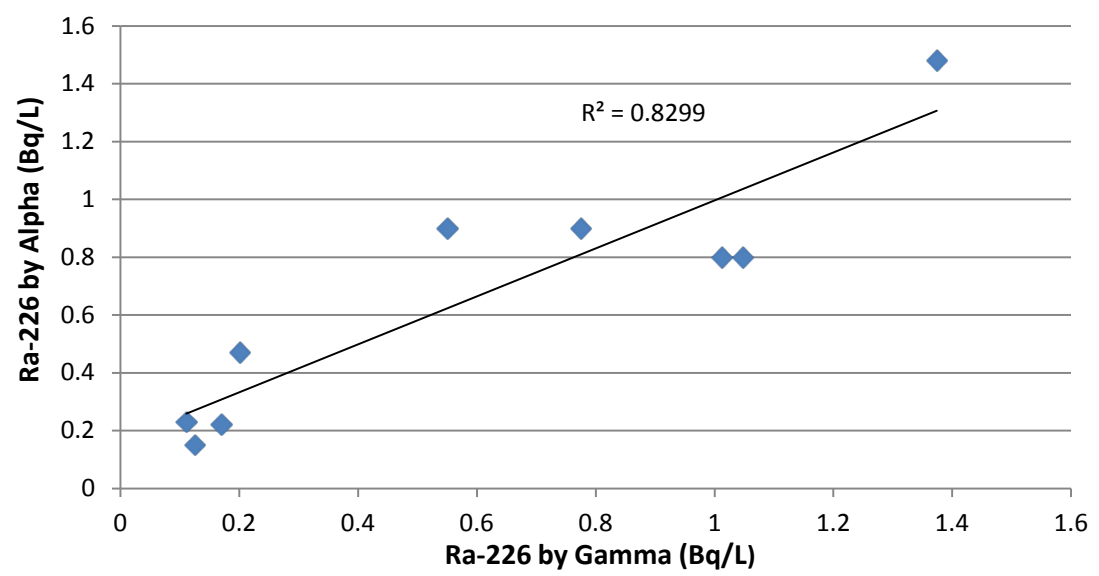

Figure 1. Comparison of Ra-226 activities determined by gamma and alpha spectrometry.

The activity concentrations of radon in Al Sharqiya water samples had an average value of $243.4 \mathrm{pCi} / \mathrm{L}$. Only two water samples have radon content exceeded the maximum contaminant level proposed by EPA for drinking water (300 $\mathrm{pCi} / \mathrm{L})$ [13]. A correlation between radon and radium was tried and the result correlation coefficient $\left(R^{2}=0.02\right)$ value revealed that the activity concentration of ${ }^{222} \mathrm{Rn}$ dissolved in groundwater in this region does not depend on the activity concentration of ${ }^{226} \mathrm{Ra}$ dissolved in the same water. This is in agreement with previous study which suggested that dissolved radon concentration in groundwater is unsupported by soluble ${ }^{226} \mathrm{Ra}$ in aquifer [14]. Low radon levels found in these wells may be attributed to the nature of aquifer rocks [15] [16]. In addition, these wells in Al Sharqiya region generally tap tertiary formations such as Dammam or Um El Radhuma aquifers which are generally limestones. Other reported study showed that the lowest radon concentration $(150 \mathrm{pCi} / \mathrm{L})$ in groundwater was from limestone bedrock [17]. Different types of natural waters have been investigated for their radon concentrations in Jeddah, Saudi Arabia. It was observed that the radon concentration in natural mineral water samples was the highest $267.5 \mathrm{pCi} / \mathrm{L}$, compared with that in tap water $46.0 \mathrm{pCi} / \mathrm{L}$ [18]. In Mecca Province, Saudi Arabia, the ${ }^{222} \mathrm{Rn}$ activity concentrations in groundwater samples were found to be in the range of $270-2700 \mathrm{pCi} / \mathrm{L}$ with an average value of $1080 \mathrm{pCi} / \mathrm{L}$ [19]. To investigate the effect of water redox conditions on the presence of radon in Al Sharqiya wells, radon activities were plotted against total dissolved solids (TDS) and oxidation reduction potential (Eh), as presented in Figure 2 and Figure 3.

As shown in Figure 2, radon activities showed good inverse correlation with the TDS content in Al Sharqiya wells. This observation is in agreement with previous conclusions in literature [20].

On the other hand, a moderate correlation was observed between radon activities in water and redox potential described by $\mathrm{R} 2$ value of 0.55 , as shown in Figure 3. Since radon is an inert gas, it is supposed not to be controlled chemically 


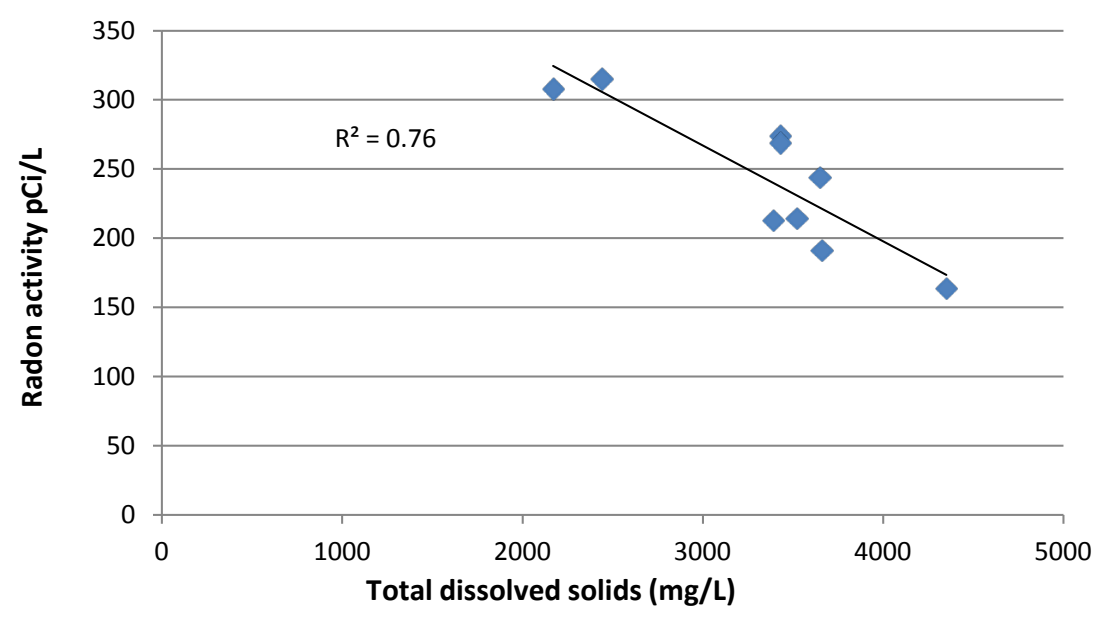

Figure 2. Correlation between radon activities and TDS in Al Sharqiya wells.

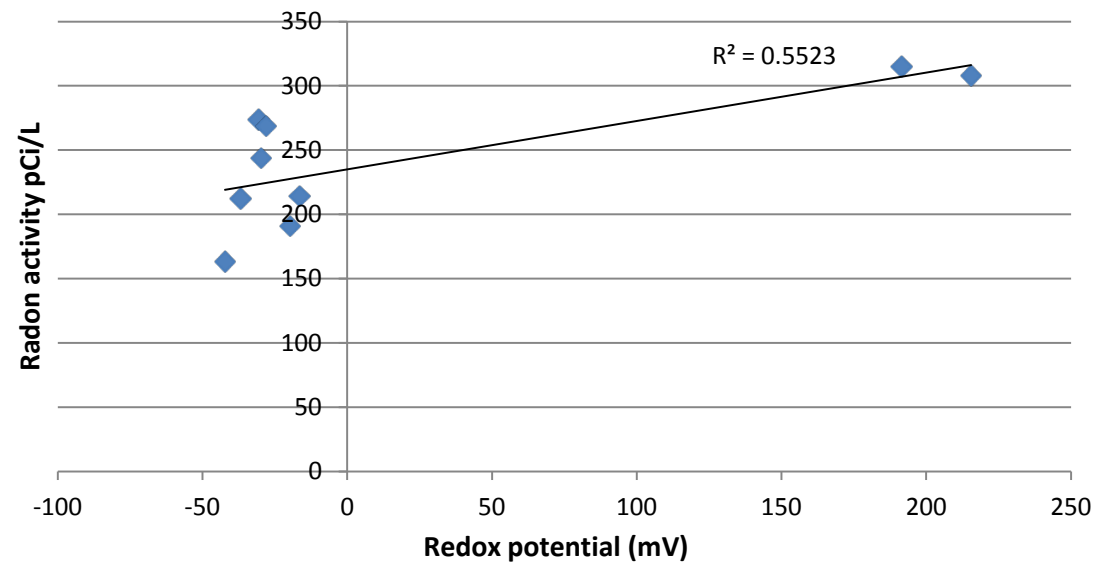

Figure 3. Correlation between radon activities and redox potential (Eh) in $\mathrm{Al}$ Sharqiya wells.

but these relationships may indicate the presence of adsorbed radium on the fractured surface of the aquifer rocks [21].

\subsection{Radon in Tabouk Groundwaters}

Table 2 presents the activity concentrations of radon and radium in Tabouk groundwater samples and the results of water chemical analyses. The activity concentrations of radon in Tabouk water samples had an average value of 441.9 $\mathrm{pCi} / \mathrm{L}$.

The presence of relatively higher ${ }^{226} \mathrm{Ra}$ activities, described by an average value of $22.6 \mathrm{pCi} / \mathrm{L}$, dissolved in these sampled water wells compared with the radium levels in Al Sharqiya samples which showed an average value of $12.9 \mathrm{pCi} / \mathrm{L}$ may be attributed to the properties of the aquifer. The sampled Tabouk wells are tapping the Saq sandstone aquifer where relatively higher uranium and radium activities were reported [6]. Many authors in literature concluded that ${ }^{222} \mathrm{Rn}$ activity concentrations in groundwaters are correlated with the ${ }^{226} \mathrm{Ra}$ concentrations in the aquifer rocks [22]. So, to investigate this observation in Tabouk ground- 
water samples, the activity concentrations of both radon and radium have been drawn as shown in Figure 4.

As presented in Figure 4, excluding one outlier showed a good positive correlation $\left(\mathrm{R}^{2}=0.7\right)$ between ${ }^{222} \mathrm{Rn}$ and ${ }^{226} \mathrm{Ra}$ in Tabouk sampled wells. As ${ }^{222} \mathrm{Rn}$ is the direct daughter of ${ }^{226} \mathrm{Ra}$, a relatively higher ${ }^{226} \mathrm{Ra}$ in bedrock is expected to generate higher levels of ${ }^{222} \mathrm{Rn}$ in water [23]. In Saudi Arabia, radon concentrations in wells tapping the Saq aquifer were found relatively higher than those tapping the Minjur limestone aquifer [24].

\section{Conclusion}

Groundwater samples were collected from private wells in Al Sharqiya and Tabouk regions in Saudi Arabia to determine the ${ }^{222} \mathrm{Rn}$ activities and to investigate if there are correlations between the obtained ${ }^{222} \mathrm{Rn}$ activities and the total dissolved solids TDS, the redox potential Eh and the ${ }^{226} \mathrm{Ra}$ activities in these

Table 2. ${ }^{222} \mathrm{Ra}$ and ${ }^{226} \mathrm{Ra}$ in Tabouk groundwater samples $\pm 1 \sigma$ uncertainties and the associated water chemistry results.

\begin{tabular}{ccccccccc}
\hline Well & $\mathrm{pH}$ & $\mathrm{T}$ & $\mathrm{Eh}$ & $\mathrm{TDS}$ & $\mathrm{Rn}-222$ & \pm & $\mathrm{Ra}-226$ & \pm \\
\hline Code & & ${ }^{\circ} \mathrm{C}$ & $\mathrm{mV}$ & $\mathrm{mg} / \mathrm{L}$ & $\mathrm{pCi} / \mathrm{L}$ & & $\mathrm{pCi} / \mathrm{L}$ & \\
W10 & 6.13 & 32.4 & 213.2 & 378 & 435.0 & 26.4 & 24.3 & 1.4 \\
W11 & 6.2 & 33.4 & 230.7 & 365 & 369.2 & 21.6 & 3.8 & 0.2 \\
W12 & 7 & 33.8 & 113.5 & 419 & 451.4 & 26.5 & 33.6 & 2.2 \\
W13 & 6.41 & 29.8 & 202 & 432 & 350.9 & 21 & 11.2 & 0.5 \\
W14 & 7.32 & 25.1 & 118.4 & 338 & 382.9 & 22.3 & 20.9 & 1 \\
W15 & 7.45 & 30.8 & 85.4 & 243 & 464.5 & 27.5 & 27.3 & 1.5 \\
W16 & 6.37 & 33.5 & 124.8 & 203 & 603.5 & 35.8 & 30.6 & 1.8 \\
W17 & 7.08 & 32.2 & 227.8 & 341 & 478.4 & 28.1 & 29.3 & 1.7 \\
\hline
\end{tabular}

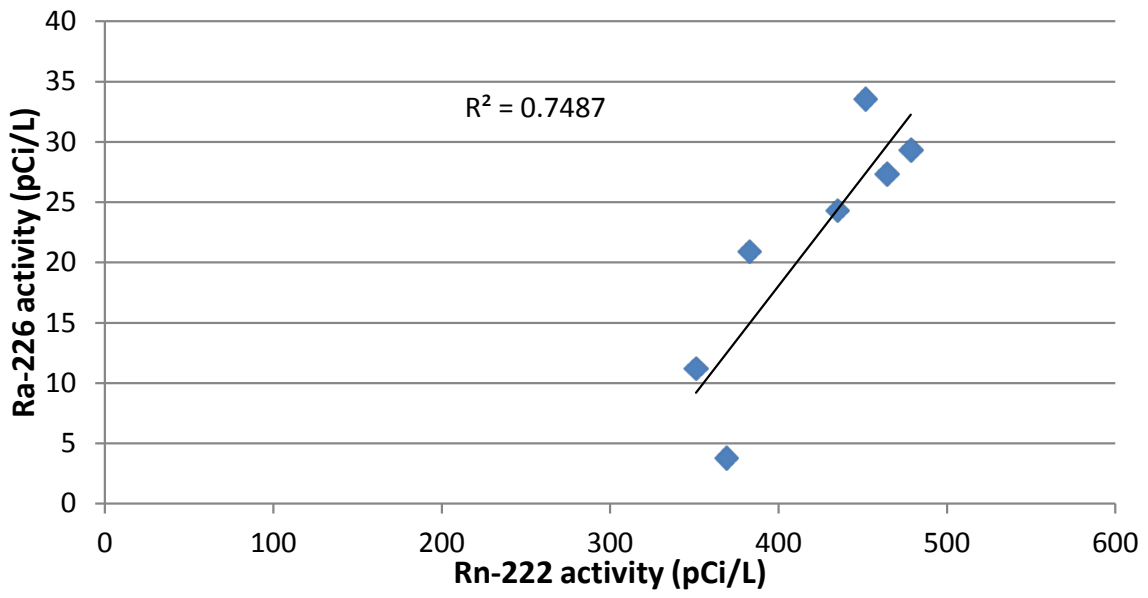

Figure 4. Correlation between radon and radium activities in Tabouk wells. 
wells. Radon measurements were carried out immediately after sampling using a silicon semiconductor detector (RAD-7), and ${ }^{226} \mathrm{Ra}$ activities were determined by gamma spectrometry after being extracted from four liters volume samples. For quality assurance, selected water samples were analyzed for ${ }^{226} \mathrm{Ra}$ using alpha spectrometry. For Al Sharqiya sampled wells, $77 \%$ of the groundwater samples were found to be below the maximum contaminant level proposed by EPA for drinking water. No statistically significant correlation was found between the activity concentrations of ${ }^{222} \mathrm{Rn}$ and ${ }^{226} \mathrm{Ra}$ in water. The radon activities showed good correlation with the total dissolved solids in Al Sharqiya groundwater wells. Also, a moderate correlation was observed between radon activities in water and the redox potential. In Tabouk wells, all the sampled wells exhibited ${ }^{222} \mathrm{Rn}$ concentrations exceeding $300 \mathrm{pCi} / \mathrm{L}$, the maximum contaminant level (MCL) recommended by the USEPA which may be explained by the nature of the Saq aquifer in this region. A good positive correlation between ${ }^{222} \mathrm{Rn}$ and ${ }^{226} \mathrm{Ra}$ in Tabouk sampled wells was observed whereas, much poorer correlations between radon activities and water chemical parameters than those of Al Sharqiya groundwater wells were observed. Within the limited number of groundwater samples, it was concluded that water chemistry plays a significant role on the presence of radon through its direct parent ${ }^{226} \mathrm{Ra}$ in $\mathrm{Al}$ Sharqiya groundwater wells. In contrast, the presence of radon in Tabouk sampled wells is may be controlled by other factors: the direct parent ${ }^{226} \mathrm{Ra}$ content and the nature of the aquifer matrix (grain size and permeability in the Saq aquifer rocks).

\section{Acknowledgements}

We express our appreciation to the Deanship of Scientific Research at Princess Nora University for funding this work through the research project 35-K-66. Also acknowledgment is extended to Technology Experts Co., Riyadh, KSA for their role in the sampling of the groundwater samples.

\section{References}

[1] Garba, N.N., Rabi'u, N., Yusuf, A.M. and Isma'ila, A. (2008) Radon: Its Consequences and Measurement in Our Living Environs. Journal of Research in Physical Sciences, 4, 23-25.

[2] Przylibski, T.A. and Gorecka, J. (2014) ${ }^{222} \mathrm{Rn}$ Activity Concentration Differences in Groundwaters of Three Variscan Granitoid Massifs in the Sudetes (NE Bohemian Massif, SW Poland). Journal of Environmental Radioactivity, 134, 43-53. https://doi.org/10.1016/j.jenvrad.2014.02.021

[3] Lubin, J.H., Boice, J.D., Edling, C., Hornung, R.W., Howe, G.R., Kunz, E., et al. (1995) Lung Cancer in Radon-Exposed Miners and Estimation of Risk from Indoor Exposure. Journal of the National Cancer Institute, 87, 817-827. https://doi.org/10.1093/jnci/87.11.817

[4] United Nations Scientific Committee on the Effects of Atomic Radiation (UNSCEAR) (2000) Report to the General Assembly with Scientific Annexes. United Nations, New York, 97-105.

[5] Schubert, M., Bürkin, W., Peña, P., Lopez, A. and Balcázar, M. (2006) On-Site De- 
termination of the Radon Concentration in Water Samples: Methodical Background and Results from Laboratory Studies and a Field-Scale Test. Radiation Measurements, 41, 492-497. https://doi.org/10.1016/j.radmeas.2005.10.010

[6] Al-Muqrin, A., Al-Ghamdi, H. and El-Sharkawy, A. (2015) Determination of Radium, Uranium and ${ }^{222} \mathrm{Rn}$ in Groundwater Samples from Different Regions in Saudi Arabia. Indian Journal of Applied Research, 5, 576-579.

[7] Durridge RAD-H2O (2013) User Manual. Radon in Water. Durridge Company Inc., Billerica.

[8] Burnett, W.C., Kim, G. and Lane-Smith, D. (2001) A Continuous Monitor For assessment of Rn-222 in the Coastal Ocean. Journal of Radioanalytical and Nuclear Chemistry, 249, 167-172. https://doi.org/10.1023/A:1013217821419

[9] El-Sharkawy, A., Ebaid, Y.Y., Burnett, W.C. and Al Daihan, S.K. (2013) A Rapid and Inexpensive Method for ${ }^{226} \mathrm{Ra}$ and ${ }^{228} \mathrm{Ra}$ Measurements of High TDS Groundwaters. Applied Radiation and Isotopes, 77, 89-93.

https://doi.org/10.1016/j.apradiso.2013.02.013

[10] ISO/IEC 17025 (2005) General Requirements for the Competence of Testing and Calibration Laboratories. International Organization for Standardization, Geneva.

[11] Currie, L.A. (1968) Limits for Qualitative Detection and Quantitative Determination. Analytical Chemistry, 40, 586-593. https://doi.org/10.1021/ac60259a007

[12] Nour, S., El-Sharkawy, A., Burnett, W.C. and Horwitz, E.P. (2004) Radium-228 Determination of Natural Waters via Concentration on Manganese Dioxide and Separation Using Diphonix Ion Exchange Resin. Applied Radiation and Isotopes, 61, 1173-1178. https://doi.org/10.1016/j.apradiso.2004.04.001

[13] United State Environmental Protection Agency (1991) National Primary Drinking Water Regulations for Radionuclides. US Government Printing Office, Washington DC.

[14] Sethy, N.K., Jha, V.N., Ravi, P.M. and Tripathi, R.M. (2015) Assessment of Human Exposure to Dissolved Radon in Groundwater around the Uranium Industry of Jaduguda, Jharkhand, India. Current Science, 109, 1855-1860.

[15] Villalba, L., et al. (2005) Radon Concentrations in Ground and Drinking Water in the State of Chihuahua, Mexico. Journal of Environmental Radioactivity, 80, 139-151. https://doi.org/10.1016/j.jenvrad.2004.08.005

[16] Cho, J.S., Ahn, J.K., Kim, H.-Ch. and Lee, D.W. (2004) Radon Concentration in Groundwater in Busan Measured with a Liquid Scintillation Counter Method. Journal of Environmental Radioactivity, 75, 105-112. https://doi.org/10.1016/j.jenvrad.2003.06.002

[17] Ogle, K.M., Eddy-Miller, C.A. and Busing, C.J. (1996) Estimated Use of Water in Lincoln County, Wyoming, 1993. U.S. Geological Survey Water-Resources Investigations Report 96-4162.

[18] Tayyeb, Z.A., Kinsara, A.R. and Farid, S.M. (1998) A Study on the Radon Concentrations in Water in Jeddah (Saudi Arabia) and the Associated Health Effects. Journal of Environmental Radioactivity, 38, 97-104.

[19] Shabana El-Said, I., Abulfaraj Waleed, H., Kinsara, A., et al. (2013) Natural Radioactivity in the Groundwater of Wadi Nu'man, Mecca Province, Saudi Arabia. Radiochimica Acta, 101, 461-470. https://doi.org/10.1524/ract.2013.2043

[20] Vinson, D.S., Vengosh, A., Hirschfeld, D. and Dwyer, G.S. (2009) Relationships between Radium and Radon Occurrence and Hydrochemistry in Fresh Groundwater from Fractured Crystalline Rocks, North Carolina (USA). Chemical Geology, 
260, 159-171. https://doi.org/10.1016/j.chemgeo.2008.10.022

[21] Krishnaswami, S., Graustein, W.C., Turekian, K.K. and Dowd, J.F. (1982) Radium, Thorium, and Radioactive Lead Isotopes in Groundwaters: Application to the in Situ Determination of Adsorption-Desorption Rate Constants and Retardation Factors. Water Resources Research, 18, 1663-1675.

https://doi.org/10.1029/WR018i006p01663

[22] Przylibski, T.A., Mamont-Cieśla, K., Kusyk, M., et al. (2004) Radon Concentrations in Groundwaters of the Polish Part of the Sudety Mountains (SW Poland). Journal of Environmental Radioactivity, 75, 193-209. https://doi.org/10.1016/j.jenvrad.2003.12.004

[23] Ball, T.K., Cameron, D.G., Colman, T.B. and Roberts, P.D. (1991) Behavior of Radon in the Geological Environment-A Review. Quarterly Journal of Engineering Geology, 24, 169-182. https://doi.org/10.1144/GSL.QJEG.1991.024.02.01

[24] Alabdulaaly, A. (2014) Occurrence of Radon in Groundwater of Saudi Arabia. Journal of Environmental Radioactivity, 138, 186-191.

https://doi.org/10.1016/j.jenvrad.2014.07.028 